\title{
In vitro Regeneration and Somatic Embryogenesis in Citrus
}

\author{
El-Sawy A. Mohamed ${ }^{1}$, Amina Gomaa ${ }^{2}$ and Nancy Danial \\ Plant Biotechnology Department, National Research Center, Dokki, Giza, Egypt \\ Key words: Citrus, In vitro regeneration, Somatic embryogenesis
}

\begin{abstract}
Better results were obtained when stigma explants of variegated lemon and citron were used. After ten months, somatic embryos developed into plantlets at a frequency ranged from 13.3 for lime to $66.7 \%$ for lemon. Virus presence was tested by ELISA and RT-PCR. The results indicated that the plantlets regenerated through somatic embryogenesis are CTV-free. RAPD analysis was used to asses the genetic stability of plantlets as compared to the mother plants. The results indicated that most plantlets belong to the respective mother plants and the polymorphism percentage was genotype and explant-dependant.
\end{abstract}

\section{Introduction}

Recent advances in tissue culture and genetic transformation offer new opportunities for the citrus genetic improvement. The development of efficient procedures for the regeneration in vitro of somatic embryos of many citrus species would be required as an intermediary for genetic transformation and improvement of genotypes. Therefore, the improvement of somatic embryo regeneration protocols of citrus is of great interest (Angela et al. 2006). The development of efficient tissue culture protocol is necessary for conservation and genetic improvement of citrus, an important fruit crop worldwide. In citrus, the production of embryogenic callus lines were reported from excised nucelli (Rangan et al. 1968), abortive ovules (Bitters et al. 1970), unfertilized ovules (Button and Bornman 1971, Pasquali and Biricolti 2004), undeveloped ovules (Starrantino and Russo 1980), juice vesicles (Nito and Iwamasa 1990), anthers (Hidaka et al. 1981 and Benelli et al. 2010), From immature seeds separated from immature fruits (Gholami 2013) styles and stigmas (Carimi et al. 1995, Angela et al. 2006 and Meziane et al. 2012) as well as from leaves, epicotyls, cotyledons (Kiong et al. 2008) and root segments (Gill et al. 1995). Moreover, tissue explants

${ }^{1}$ Author for correspondence: <adelelsawy05@yahoo.com>. Department of Pomology, Faculty of Agriculture, Caitro University, Giza, Egypt. 
and embryogenic cells have, generally, a high capacity to regenerate plants and can be used in protoplast fusion and genetic transformation (Vardi and Galun 1989, Vardi and Spiegel-Rov 1992, Tavano et al. 2009). Although in the genus Citrus somatic embryogenesis was reported a long time ago (Maheshwari and Rang Swamy 1958), a number of difficulties have been encountered in establishing reliable protocols. In the abundant literature on Citrus somatic embryogenesis, it appears that results vary greatly depending on the genotypes (Mendes-da-Gloria et al. 2001, Tomaz et al. 2001, Niedz et al. 2002, Ramirez et al. 2003). The embryogenic potential of citrus varied with genotype and type of explant. Regeneration methods that involve the use of embryogenic callus of nucellar origin generally provide the best results. Unfortunately these systems provide only poor results with monoembryonic species. Kobayashi et al. (1981) cultured the ovules of 23 monoembryonic cultivars and never obtained nucellar embryos and in some genotypes characterized by low levels of polyembryos; for example, many cultivars of lemon. Somatic embryogenesis could be obtained through intact stigma and style culture (De pasquali et al. 1994, Carimi et al. 1995, 1998, 1999), which led to the question of whether such an embryogenic potential could be expressed in all the different parts of the pistil and in structures such as thin cell layer (TCL) explants. Although somatic embryogenesis, especially from ovule tissue and embryos developed from ovules, have been extensively investigated in citrus, there are only a few reports on somatic embryogenesis from somatic tissue that is neither nucellar nor ovular in origin. Little is known about the effect of tissue type on somatic embryogenesis in citrus. The use of stigma and style culture as explant for somatic embryogenesis was successfully applied in preliminary trials for sanitizing lemon affected by a mixture of graft-transmissible agents, amongst which CPsV may not have been present (D'Onghia et al. 1997, 2001). The main objective of this investigation was to produce citrus plants through somatic embryogenesis from stigma, style and ovary. Moreover, resulting plantlets were investigated for virus presence as well as genetic stability.

\section{Materials and Methods}

Flower buds of different citrus species and cultivars illustrated in Fig. 1A were harvested just before opening from mature trees of different species and cultivars of citrus as mentioned in Table 1 grown at, Moshtohor, Kalubia, Egypt.

Flower buds were washed carefully with running tap water and surface sterilized by immersing in $70 \%(\mathrm{v} / \mathrm{v})$ ethanol for $1 \mathrm{~min}$, then soaked in a $38 \%$ Clorox [commercial bleach (2\% sodium hypochlorite solution)] for $15 \mathrm{~min}$, followed by three $5 \mathrm{~min}$ rinses in sterile distilled water. Stigma, style and ovary 
explants were excised from flower buds with a scalpel under aseptic conditions and placed vertically onto the culture medium, explants were initially cultured on MS basal salts and vitamins amended with $3 \mathrm{mg} / \mathrm{l} \mathrm{BA}$ for callus initiation. For somatic embryogenesis callus drived from stigma, style and ovary were subcultured on MS supplemented with sucrose $50 \mathrm{~g} / \mathrm{l}$, malt extract $500 \mathrm{mg} / \mathrm{l}$ and $3.0 \mathrm{mg} / \mathrm{l} \mathrm{BA}$ and solidified with $7 \mathrm{~g} / \mathrm{l}$ Difco Bacto agar. The $\mathrm{pH}$ of the medium was adjusted to 5.8 autoclaved at $121^{\circ} \mathrm{C}$ for $25 \mathrm{~min}$. An average of 10 explants were cultured in each Petri dish $(10 \mathrm{~cm}$ diam.) containing $20 \mathrm{ml}$ of the culture medium and sealed with parafilm $\mathrm{M}$.

Table 1. List of common and scientific name of different species and cultivars of citrus trees under investigation.

\begin{tabular}{cll}
\hline Sl. No. & Common name & Scientific name \\
\hline 1 & Washington navel orange & C. sinensis (L.) \\
2 & Satsuma mandarin & C. unshiu (Mak.) \\
3 & Lemon & C. limon (L.) \\
4 & Variegated lemon & C. limon (L.) \\
5 & Lime & C. aurantifolia (Christm.) \\
6 & Citron & C. medica (L.) \\
7 & Pummelo & C. grandis (L.) \\
8 & Rough lemon & C. jambhiri (Lush.) \\
9 & Sour orange & C. aurantium (L.) \\
10 & Volkamer lime & C. volkameriana (Ten. \& Posg.) \\
11 & Rangpur lime & C. limonia (Osb.) \\
\hline
\end{tabular}

Cultures were incubated at $25 \pm 1^{\circ} \mathrm{C}$ under a $16 \mathrm{hrs}$ day length with illuminetion of $100 \mu \mathrm{mol} / \mathrm{m}^{-2} / \mathrm{s}^{-1}$ Osram cool white $18 \mathrm{w}$ fluorescent tubes. After four weeks, cultures were transferred to a fresh medium in $250 \mathrm{ml}$ jars filled with 30 $\mathrm{ml}$ of the same medium. All culture explants were subcultured at four weeks intervals on the same fresh culture medium up to ten weeks.

Somatic embryos ( $1-2 \mathrm{~mm}$ in diam.) arising from embryogenic calli were isolated and cultured into test tube $(25 \times 150 \mathrm{ml})$ containing $20 \mathrm{ml}$ of MS solid medium (7 g/l agar) supplemented with $50 \mathrm{~g} / \mathrm{l}$ sucrose and $1 \mathrm{mg} / \mathrm{l} \mathrm{GA}$. Culture tubes were sealed with aluminium foil. The $\mathrm{pH}$ was adjusted to $5.8 \pm 0.1$ with 0.5 $\mathrm{M}$ sodium hydroxide before autoclaved at $121^{\circ} \mathrm{C}$ for $25 \mathrm{~min}$. The culture tubes were kept in the culture room at $27^{\circ} \mathrm{C}$ and exposed to a $16 \mathrm{hrs}$ day length, with illumination of $100 \mu \mathrm{mol} / \mathrm{m}^{-2} / \mathrm{s}^{-1}$ Osram cool - white $18 \mathrm{w}$ fluorescent lamps. Embryo germination was count for a period of ten months weekly.

All experiments were set up as a randomized complete design with three replicates for each treatment with at least 10 explants per replicate $(n=30)$. Data were subjected to ANOVA with mean separation $(p=0.05)$ by DMRT using SAS ver.6.12(SAS Institute, Cary, NC, USA). 
Genomic DNA was isolated on a mini-prep scale as mentioned by Murray and Thomposon (1980). Small pieces (0.5 g) of young leaves of citrus species growing under field conditions and tissue culture-derived plantlets were frozen in liquid nitrogen in Eppendorf tubes and homogenized in $500 \mu \mathrm{l}$ of extraction buffer (2\% CTAB, 1.4 M NaCl, 20 mM EDTA pH 8.0, $100 \mathrm{mM}$ Tris-HCl, pH 8.0, $0.1 \mathrm{M}$ ß-mercaptoethanol). The extract was incubated at $60^{\circ} \mathrm{C}$ for $20 \mathrm{~min}$. To this $500 \mu$ lof phenol : chloroform : isoamyl alcohol (24:24:1) were added and mixed by vortexing for $30 \mathrm{sec}$ followed by centrifugation at 10,000 $\mathrm{xg}$ for $5 \mathrm{~min}$ at room temperature. The aqueous phase was transferred to another tube. This was once again extracted with $500 \mu \mathrm{l}$ of chloroform: isoamyl alcohol (24:1) in Eppendorf tube. To the aqueous phase, 0.6 volume of isopropanol were added, precipitated the genomic DNA and spooled the fibrous genomic DNA. Genomic DNA was then washed three times with $70 \%$ ethanol, dried in vacuum, dissolved in TE containing $10 \mathrm{mg} / \mathrm{ml} \mathrm{RNase}$ and incubated at $37^{\circ} \mathrm{C}$ for $30 \mathrm{~min}$, followed by extraction with phenol: chlorform: isoamyl alcohol and the aqueous phase was transferred to a fresh tube. Therafter, the genomic DNA was precipitated by adding $0.3 \mathrm{M}$ sodium acetate, $\mathrm{pH} 5.2$ (final concentration) and $2.5 \mathrm{vol}$ of ethanol and collected by centrifugation at $10,000 \mathrm{xg}$ for $20 \mathrm{~min}$ at $4^{\circ} \mathrm{C}$. The pellet was washed with $70 \%$ ethanol, vacuum dried and dissolved in TE.

Reactions for RAPD analysis were set up using seven random oligonucleotide (10 mer) primers (Operon technologies Inc., Alameda, California). The primers are OPK01 (5' TGC CGA GCT G 3'), OPK02 (5' GTG AGG CGT C 3'), OPK03 ( $5^{\prime}$ CCC TAC CGA C 3' ), OPK04 (5' TCG TTC CGC A 3'), OPK05 (5' CAC CTT TCC C 3'), OPK06 (5' GAG GGA AGA G 3') and OPK07 (5' CCA CAG CAG T 3'). The PCR reactions were carried out in $50 \mu$ volumes containing $100 \mathrm{ng}$ of genomic DNA, $1.0 \mu \mathrm{M}$ primer, $200 \mu \mathrm{M}$ of dATP, dDTP, dCTP, dGTP, $10 \mathrm{mM}$ tris- $\mathrm{HCl}, \mathrm{pH} 8.3,50 \mathrm{mM} \mathrm{KCl}, 1.5 \mathrm{mM} \mathrm{MgCl}_{2}$ and $0.001 \%$ gelatine. The Taq DNA polymerase concentration was 1.5 units per assay. PCR reaction was conducted using a Perkin Elmer 2400 (Germany) thermocycler programmed as follows : $94^{\circ} \mathrm{C} / 5 \mathrm{~min}(1 \mathrm{cycle}), 94^{\circ} \mathrm{C} / 30 \mathrm{sec}, 36^{\circ} \mathrm{C} / 30 \mathrm{sec}, 72^{\circ} \mathrm{C} / 2$ $\min \left(45\right.$ cycle) and $72^{\circ} \mathrm{C} / 7 \mathrm{~min}(1 \mathrm{cycle})$, then held at $4^{\circ} \mathrm{C}$. The amplification products of PCR were size-separated by gel electrophoresis in $1 \%$ agrose gels with 1 x TBE buffer using a Pharmacia G N. 100 submarine gel electrophoresis apparatus and stained with ethidium bromide and visualized with UV transilluminator and photographed. A 100 bp DNA ladder (Promega) was used as a standard with molecular sizes of 1000, 900, 800, 700, 600, 500, 400, 300, 200 and $100 \mathrm{bp}$. DICE computer package was used for the analysis of RAPD-PCR products (Yang and Quiros 1993). 
CTV infection was assayed in somatic embryogenesis derived plantlets obtained by a double antibody sandwich enzyme-linked immunosorbent assay (DAS-ELISA) (Clark and Adams 1977). It was carried out according to the manufatcor instructions. The $\mathrm{A}_{405} \mathrm{~nm}$ value of each well was measured by an enzyme immunosorbent assay plate reader (Model 3550 microplate reader).

The two-step RT-PCR was performed and included two separate steps: reverse transcription and PCR amplification. Reverse transcription for the synthesis of the first strand cDNA was made by Superscript ${ }^{\mathrm{TM}}$ II RNase HReverse Transcriptase (Bioron). The total volume was $20 \mu \mathrm{I}$, which contained 50 units of Superscript ${ }^{\mathrm{TM}}$ II reverse transcriptase, $50 \mathrm{mM}$ Tris-HCL (PH 8.3), $75 \mathrm{mM}$ KCL, $3 \mathrm{mM} \mathrm{MgCl}_{2}, 10 \mathrm{mM}$ DTT, 2 pmol reverse primer 5' TCA ACG TGT GTT GAA TTT CCC AAG C 3' , 0.5 mM each dATP , dTTP, dCTP, dGTP, and 200ng of nucleic acid preparations. The contents (RT mixture) were mixed gently and incubated at $42^{\circ} \mathrm{C}$ for $50 \mathrm{~min}$. The PCR amplification was performed using $25 \mu \mathrm{l}$ of reaction mixture containing $20 \mathrm{mM}$ tris- $\mathrm{HCl}(\mathrm{pH} 8.4), 50 \mathrm{mM} \mathrm{KCL}, 1.5 \mathrm{mM}$ $\mathrm{MgCl}_{2}, 0.2 \mathrm{mM}$ each dATP , dTTP, dCTP, dGTP, 5 pmol forward primer $5^{\prime}$ AAC GCC CTT CGA GTC TGG GGT AGG A 3', 5 pmol reverse primer 5' TCA ACG TGT GTT GAA TTT CCC AAG C $3^{\prime}$ as reported by Rowhani et al. (1998), 1.25 units of Taq DNA polymerase, and $2 \mu \mathrm{I}$ of RT mixture. The thermal cycle conditions were: one cycle at $94^{\circ} \mathrm{C}$ for $5 \mathrm{~min} ; 30$ cycles at $94^{\circ} \mathrm{C}$ for $30 \mathrm{~s}, 57^{\circ} \mathrm{C}$ for 30 $\mathrm{s}, 72^{\circ} \mathrm{C}$ for $1 \mathrm{~min}$ : followed by $72^{\circ} \mathrm{C}$ extension for $10 \mathrm{~min}$.

\section{Results and Discussion}

Friable-yellow callus (Fig. 1b,c) initiated from stigma, style and ovary explants could be observed after 2 - 3 weeks of incubation. (Table 2) indicated frequencies of callus initiation from different explants scored after four weeks of incubation. The callusing percentage was affected by genotype and type of explant, also different genotypes showed significant differences in callus initiation frequencies. Washington navel orange explants showed the highest callus formation mean percentage (59.5) whereas the lowest mean (1.7) was observed in Satsuma mandarin explants. The type of explant showed a significant effect on callus induction as shown in (Table 2). Maximum callusing percentage was observed with ovary explants as a mean of all genotypes (42.0) followed by stigma and style explants (33.5 and 20.9), respectively. The interaction between genotype and type of explant showed that style explants of Washington navel orange was the best responding explant $(100 \%)$, followed significantly by ovary explants of Rangpur lime and stigma explants of Citron without significant difference (71.4 and 68.4\%), respectively. Ovary explants for both Washington navel orange and Lime came next without significant difference between them 
(57.10 and 57.12\%, respectively). On the other hand, no response could be detected from style explants of Satsuma mandarin, Lime, Pummelo and Sour orange and stigma explants of Satsuma mandarin for callus initiation.

Table 2. Callusing percentage of different citrus genotypes and explants (after 4 weeks).

\begin{tabular}{|c|c|c|c|c|}
\hline \multirow{3}{*}{ Genotype } & \multicolumn{4}{|c|}{ Callusing $(\%)$} \\
\hline & \multicolumn{4}{|c|}{ Explant type } \\
\hline & Style & Stigma & Ovary & Mean \\
\hline Washington navel orange & 100 a & 21.41 & $57.10 \mathrm{c}$ & $59.5 \mathrm{~A}$ \\
\hline Satsuma mandarin & $0.0 \mathrm{p}$ & $0.0 \mathrm{p}$ & $5.0 \quad$ o & $1.7 \mathrm{H}$ \\
\hline Rough lemon & $14.3 \mathrm{~m}$ & $33.3 \mathrm{ij}$ & $50.0 \mathrm{~d}$ & $32.5 \mathrm{DE}$ \\
\hline Lemon & $13.3 \mathrm{~m}$ & $33.3 \mathrm{ij}$ & 42.8 ef & $29.8 \mathrm{~F}$ \\
\hline Lime & $0.0 \mathrm{p}$ & 46.7 de & $57.12 \mathrm{c}$ & $34.6 \mathrm{D}$ \\
\hline Variegated Lemon & 46.2 de & $36.0 \mathrm{hi}$ & $30.8 \mathrm{jk}$ & $37.7 \mathrm{C}$ \\
\hline Pummelo & $0.0 \mathrm{p}$ & $50.0 \mathrm{~d}$ & $50.0 \mathrm{~d}$ & $33.3 \quad \mathrm{EF}$ \\
\hline Citron & $38.1 \mathrm{gh}$ & $68.4 \mathrm{~b}$ & $28.6 \mathrm{k}$ & $45.1 \mathrm{~B}$ \\
\hline Rangpur lime & $9.1 \mathrm{n}$ & 35.7 hi & $71.4 \mathrm{~b}$ & $38.7 \mathrm{C}$ \\
\hline Volkamer lime & $9.4 \mathrm{n}$ & $36.1 \mathrm{hi}$ & $41.7 \mathrm{fg}$ & $29.1 \mathrm{~F}$ \\
\hline Sour orange & $0.0 \mathrm{p}$ & 7.2 no & $28.0 \mathrm{k}$ & $11.7 \mathrm{G}$ \\
\hline Mean & $20.9 \mathrm{C}$ & $33.5 \mathrm{~B}$ & $42.0 \mathrm{~A}$ & \\
\hline
\end{tabular}

Different letters within a column indicate significant differences at $p<0.05$ according to DMRT.

Somatic embryos appeared after 2 - 3 months of culture as shown in Fig. 1-d. (Table 3) indicated that somatic embryogenesis was significantly affected by genotype and type of explant. There were significant differences in somatic embryos frequencies among the genotypes. Variegated Lemon produced the highest significant mean percentage of somatic embryogenesis (44.1\%) followed significantly by the somatic embryogenesis percentage of Citron $(11.7 \%)$ and Sour orange $(6.7 \%)$ with significant difference. Rough lemon and Lime showed the same percentage of somatic embryogenesis (6.1). On the other hand, all explants of Washington navel orange, Satsuma mandarin, Pummelo, Rangpur lime and Volkamer lime could not produce any somatic embryo assayed.

Somatic embryogenesis was also affected by the type of explant, somatic embryogenesis of stigma explants $(13.0 \%)$ were significantly the highest than style $(6.4 \%)$ or ovary explants $(1.8 \%)$. Also, the best explant for producing somatic embryos varied according to the genotype where stigma explants were the best for Variegated lemon $(80.0 \%)$ followed significantly by style explants for the same genotype (52.4\%). Generally, stigma explants gave the highest results for the most citrus genotypes tested. 
Number of produced somatic embryos is presented in (Table 3 and Fig. 1-e). In Table 3 it was clear that number of embryo was significantly affected by genotype and type of explant. Citron produced the highest significant mean number of embryos/explant derived embryogenic callus (11.0), whereas Sour orange produced the lowest number of embryos/explant (0.3) after ten months. Otherwise, in Washington navel orange, Satsuma mandarin, Pummelo, Rangpur lime and Volkamer lime, no embryos were induced from different explantsderived embryogenic callus. Belong to explant type, stigma explants produced an averaged 4.2 embryos/explant, higher significantly than style (2.8) or ovary (0.2).

Table 3. Somatic embryogenesis percentage of different citrus genotypes and explants (after 3 months).

\begin{tabular}{|c|c|c|c|c|c|c|}
\hline \multirow{3}{*}{ Genotype } & \multicolumn{6}{|c|}{ Somatic embryogenesis (\%) } \\
\hline & \multicolumn{6}{|c|}{ Explant type } \\
\hline & Style & \multicolumn{2}{|c|}{ Stigma } & \multicolumn{2}{|c|}{ Ovary } & Mean \\
\hline Washington navel orange & $0.0 \mathrm{~g}$ & 0.0 & $\mathrm{~g}$ & 0.0 & $\mathrm{~g}$ & $0.0 \mathrm{~F}$ \\
\hline Satsuma mandarin & $0.0 \mathrm{~g}$ & 0.0 & $\mathrm{~g}$ & 0.0 & $\mathrm{~g}$ & $0.0 \mathrm{~F}$ \\
\hline Rough lemon & $0.0 \mathrm{~g}$ & 18.2 & $\mathrm{e}$ & 0.0 & g. & $6.1 \mathrm{D}$ \\
\hline Lemon & $10.0 \mathrm{f}$ & 0.0 & $\mathrm{~g}$ & 0.0 & $\mathrm{~g}$ & $3.3 \mathrm{E}$ \\
\hline Lime & $0.0 \mathrm{~g}$ & 18.2 & $\mathrm{e}$ & 0.0 & $\mathrm{~g}$ & $6.1 \mathrm{D}$ \\
\hline Variegated Lemon & $52.4 \mathrm{~b}$ & 80.0 & a & 0.0 & $\mathrm{~g}$ & $44.1 \mathrm{~A}$ \\
\hline Pummelo & $0.0 \mathrm{~g}$ & 0.0 & $\mathrm{~g}$ & 0.0 & $\mathrm{~g}$ & $0.0 \mathrm{~F}$ \\
\hline Citron & $8.3 \mathrm{f}$ & 26.7 & c & 0.0 & $\mathrm{~g}$ & $11.7 \mathrm{~B}$ \\
\hline Rangpur lime & $0.0 \mathrm{~g}$ & 0.0 & $\mathrm{~g}$ & 0.0 & $\mathrm{~g}$ & $0.0 \mathrm{~F}$ \\
\hline Volkamer lime & $0.0 \mathrm{~g}$ & 0.0 & $\mathrm{~g}$ & 0.0 & $\mathrm{~g}$ & $0.0 \mathrm{~F}$ \\
\hline Sour orange & $0.0 \mathrm{~g}$ & 0.0 & $\mathrm{~g}$ & 20.0 & $\mathrm{~d}$ & $6.7 \mathrm{C}$ \\
\hline Mean & $6.4 \mathrm{~B}$ & 13.0 & $\mathrm{~A}$ & 1.8 & $\mathrm{C}$ & \\
\hline
\end{tabular}

Different letters within a column indicate significant differences at $p<0.05$ according to DMRT.

Somatic embryos were transferred to MS supplemented with $50 \mathrm{~g} / \mathrm{l}$ sucrose and $1 \mathrm{mg} / \mathrm{l}$ of $\mathrm{GA}_{3}$ as shown in Fig. 1f and left to maturity and complete germination as shown in Fig. 1g. The highest germination percentage of embryos was 66.7 observed in Lemon followed by $48.2 \%$ for Citron with a significant difference between them. Embryos produced from stigma explants were superior in germination compared to drived from style or ovary explants (25.4, 20.0 and $18.2 \%$, respectively) as shown in (Table 4). Finally, it can be conculaded that, ovary explants produced the highest percentage of callusing whereas stigma was the best explant for embryogenesis and number of embryos. Washington navel orange was superior to other genotypes for callus formation. But Variegated lemon and citron were the most producing genotypes of somatic embryos. 
Table 4. Number of embryos of different citrus genotype and explants (after ten months).

\begin{tabular}{lcccc}
\hline \multirow{2}{*}{ Genotype } & \multicolumn{5}{c}{ Number of embryo/explant } \\
\cline { 2 - 5 } & \multicolumn{5}{c}{ Stigma } & Ovary & Mean \\
\cline { 2 - 6 } & Style & $0.0 \mathrm{i}$ & $0.0 \mathrm{i}$ & $0.0 \mathrm{G}$ \\
Washington navel orange & $0.0 \mathrm{i}$ & $0.0 \mathrm{i}$ & $0.0 \mathrm{i}$ & $0.0 \mathrm{G}$ \\
Satsuma mandarin & $0.0 \mathrm{i}$ & $2.7 \mathrm{~g}$ & $0.0 \mathrm{i}$ & $0.9 \mathrm{E}$ \\
Rough lemon & $0.0 \mathrm{i}$ & $0.0 \mathrm{i}$ & $1.0 \mathrm{~h}$ & $2.7 \mathrm{C}$ \\
Lemon & $7.0 \mathrm{e}$ & $6.7 \mathrm{f}$ & $0.0 \mathrm{i}$ & $2.3 \mathrm{D}$ \\
Lime & $0.0 \mathrm{i}$ & $16.4 \mathrm{~b}$ & $0.0 \mathrm{i}$ & $9.3 \mathrm{~B}$ \\
Variegated Lemon & $11.2 \mathrm{~d}$ & $0.0 \mathrm{i}$ & $0.0 \mathrm{i}$ & $0.0 \mathrm{G}$ \\
Pummelo & $0.0 \mathrm{i}$ & $20.5 \mathrm{a}$ & $0.0 \mathrm{i}$ & $11.0 \mathrm{~A}$ \\
Citron & $12.5 \mathrm{c}$ & $0.0 \mathrm{i}$ & $0.0 \mathrm{i}$ & $0.0 \mathrm{G}$ \\
Rangpur lime & $0.0 \mathrm{i}$ & $0.0 \mathrm{i}$ & $0.0 \mathrm{i}$ & $0.0 \mathrm{G}$ \\
Volkamer lime & $0.0 \mathrm{i}$ & $0.0 \mathrm{i}$ & $1.0 \mathrm{~h}$ & $0.3 \mathrm{~F}$ \\
Sour orange & $0.0 \mathrm{i}$ & $4.2 \mathrm{~A}$ & $0.2 \mathrm{C}$ & \\
Mean & $2.8 \mathrm{~B}$ & &
\end{tabular}

Different letters within a column indicate significant differences at $\mathrm{p}<0.05$ according to Duncan's New Multiple range test.

Table 5. Percentage of somatic embryo germination of different citrus genotypes and explants type (after ten months).

\begin{tabular}{lcccccc}
\hline & \multicolumn{7}{c}{ Embryo germination (\%) } \\
\cline { 2 - 6 } Genotype & \multicolumn{7}{c}{ Explant type } \\
\cline { 2 - 7 } & \multicolumn{7}{c}{ Style } & Stigma & Ovary & Mean \\
\cline { 2 - 7 } Washington navel orange & 0.0 & $\mathrm{~g}$ & 0.0 & $\mathrm{~g}$ & $0.0 \mathrm{~g}$ & $0.0 \mathrm{~F}$ \\
Satsuma mandarin & 0.0 & $\mathrm{~g}$ & 0.0 & $\mathrm{~g}$ & $0.0 \mathrm{~g}$ & $0.0 \mathrm{~F}$ \\
Rough lemon & $0.0 \mathrm{~g}$ & $100 \mathrm{a}$ & $0.0 \mathrm{~g}$ & $33.3 \mathrm{D}$ \\
Lemon & $100.0 \mathrm{a}$ & $0.0 \mathrm{~g}$ & $100.0 \mathrm{a}$ & $66.7 \mathrm{~A}$ \\
Lime & $0.0 \mathrm{~g}$ & $40.0 \mathrm{f}$ & $0.0 \mathrm{~g}$ & $13.3 \mathrm{E}$ \\
Variegated Lemon & $56.1 \mathrm{e}$ & $58.6 \mathrm{~d}$ & $0.0 \mathrm{~g}$ & $38.2 \mathrm{C}$ \\
Pummelo & $0.0 \mathrm{~g}$ & $0.0 \mathrm{~g}$ & $0.0 \mathrm{~g}$ & $0.0 \mathrm{~F}$ \\
Citron & $64.0 \mathrm{c}$ & $80.5 \mathrm{~b}$ & $0.0 \mathrm{~g}$ & $48.2 \mathrm{~B}$ \\
Rangpur lime & $0.0 \mathrm{~g}$ & $0.0 \mathrm{~g}$ & $0.0 \mathrm{~g}$ & $0.0 \mathrm{~F}$ \\
Volkamer lime & $0.0 \mathrm{~g}$ & $0.0 \mathrm{~g}$ & $0.0 \mathrm{~g}$ & $0.0 \mathrm{~F}$ \\
Sour orange & $0.0 \mathrm{~g}$ & $0.0 \mathrm{~g}$ & $100.0 \mathrm{a}$ & $33.3 \mathrm{D}$ \\
Mean & $20.0 \mathrm{~B}$ & $25.4 \mathrm{~A}$ & $18.2 \mathrm{C}$ & \\
\hline
\end{tabular}

Different letters within a column indicate significant differences at $p<0.05$ according to Duncan's New Multiple range test.

Our results showed that the embryogenic potential of stigma explants are usually higher than style. However, De Pasquale et al. 1994 and Carimi et al. 1995, demonstrated that stigma never regenerated somatic embryos and rarely 
produce callus when stigma and style were jointly cultured. In addition, the direct contact of explant with the culture medium may be an additional factor in the high frequency induction of somatic embryogenesis (Gill et al. 1993). The embryogenic potential has been demonstrated in different parts of the flower.In others report somatic embryos were regenerated from the immature inflorescences of Sporoblus virginicus (L.) Kunth (Straub et al. 1992).

Somatic embryogenesis from pistils cultures was obtained in Dactylis glomerata (L.) (Songstad and Conger 1986) and in a hybrid of Cichorium (Guerida et al. 1988), from ovary cultures in fuchsia (Dabin and Beguin 1987), Vitis vinifera (L.) (Goussard et al. 1991), Allium cepa (L.) (Campion et al. 1992) and Caryratia japonica (Zhou et al. 1994). However, somatic embryogenesis from styles or stigmas cultured separately has not been reported in the literature.
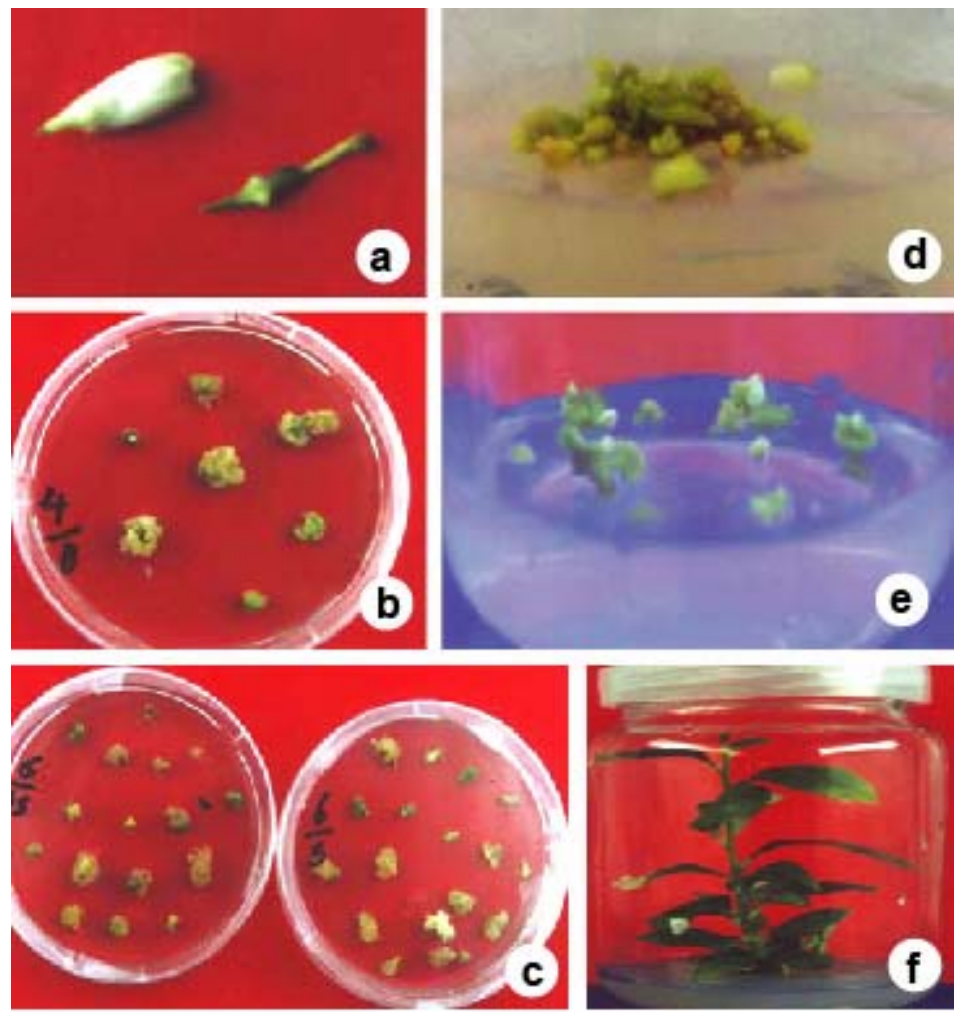

Fig. 1. (a) Citrus flower bud (just before opening) used as a source of explants (style-stigma-ovary).

(b) Callus formation on ovary explants of lemon (C. limon) after 3 week of culture. (c) Callus formation on style(s) and stigma (ss) explants of lemon (C. limon) after 3 week of culture. (d) Somatic embryos on callus derived from stigma explants. (e) Embryo development at cotyledonary stage growing on germination medium. (f) Style-derived plantlet after 3 months on germination medium. 
In our study, a procedure for culturing of stigma, style and ovary from different genotype of citrus has been established. These explants showed different embryogenic potentials on the same medium (MS salts $+50 \mathrm{~g} / \mathrm{l}$ sucrose $+500 \mathrm{mg} / \mathrm{l} \mathrm{malt}$ extract $+3 \mathrm{mg} / \mathrm{l}$ of BA). Our results indicated that lemon and citron are the best genotype to produce somatic embryogenesis. Somatic embryogenesis from citrus stigma and style culture has been descried as a new technique for the sanitation, conservation and safe exchange of citrus germplasm (D'Onghia et al. 2000). This improved method can be successfully applied to the propagation of plants free from graft transmissible pathogens (D 'Onghia et al. 1997, 2001).

The choice of plant growth regulators determines both the ability of the explant to respond and the mode of the morphogenic reaction and usually somatic embryogenesis is induced in the presence of auxin alone or in combination with cytokinins (Gaj 2004). In only few systems cytokinins supplemented alone were found to be effective in somatic embryogenesis induction (Carimi et al. 1999, Nanda and Rout 2003).

Standard DAS-ELISA test as described by Clark and Adams (1977) failed to detect CTV from regenerated plantlets of citrus in that the OD 504 values of all the samples tested were low to be differentiated from negative controls as shown in Table 6. Our data indicated that standard DAS-ELISA could be used successfully in detection of CTV. Although simpler and quicker the standard DAS-ELISA was shown to be ineffective.

Table 6. Detection of citrus tristeza virus in stigma, style and ovary-derived plantlets via DAS-ELISA.

\begin{tabular}{|c|c|c|c|c|c|c|}
\hline \multirow[t]{2}{*}{ S1. No. } & \multirow[t]{2}{*}{ Genotype } & \multirow[t]{2}{*}{ Explant } & \multicolumn{3}{|c|}{ O.D.504 value } & \multirow[t]{2}{*}{ Results } \\
\hline & & & $\mathrm{R} 1$ & $\mathrm{R} 2$ & Mean & \\
\hline \multirow[t]{2}{*}{1} & Lemon & Style & 0.091 & 0.106 & 0.098 & - \\
\hline & & Ovary & 0.098 & 0.090 & 0.094 & - \\
\hline 2 & Lime & Stigma & 0.113 & 0.089 & 0.101 & - \\
\hline \multirow[t]{2}{*}{3} & & Stigma & 0.102 & 0.094 & 0.098 & - \\
\hline & Citron & Style & 0.111 & 0.092 & 0.102 & - \\
\hline 4 & Rough lemon & Stigma & 0.091 & 0.106 & 0.098 & - \\
\hline \multirow[t]{2}{*}{5} & Variegated & Stigma & 0.089 & 0.092 & 0.091 & - \\
\hline & Lemon & Style & 0.083 & 0.084 & 0.084 & - \\
\hline+ & Positive & - & 1.096 & 0.880 & 0.988 & + \\
\hline- & Negative & - & 0.108 & 0.081 & 0.095 & - \\
\hline
\end{tabular}

+ Positive control (infected), - Negative control (healthy), R : replicate.

Results of RT-PCR analysis are shown in Fig. 2. They indicated detectable band resulting from RT-PCR products of $300 \mathrm{bp}$ using the primers reported by 
Rowhani et al. (1998), and all the tested samples were negative, no detectable expected size band (300 bp) as shown in (Fig. 2).

In fact, no CTV was detected in any of the regenerated plantlets using ELISA techniques or RT-PCR methods confirming that all plantlets resulted via somatic embryogenesis derived from stigma, style and ovary are CTV-free.

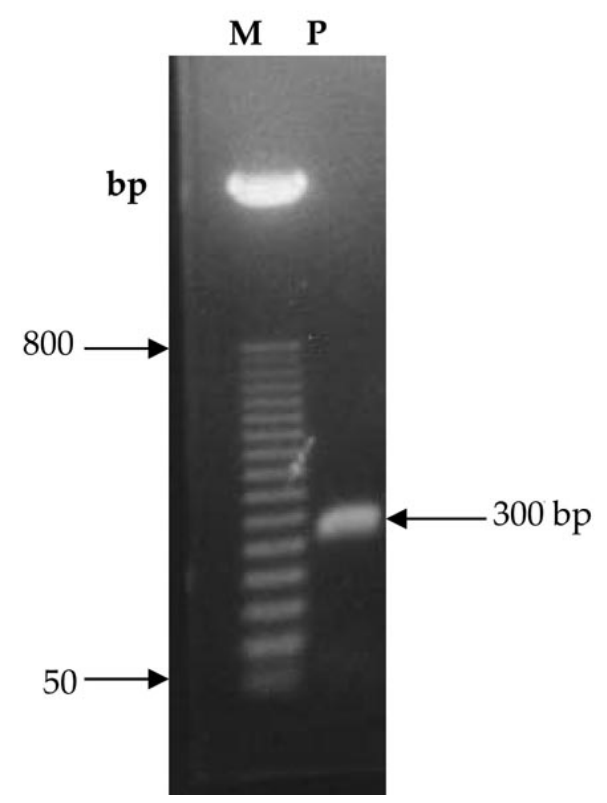

Fig. 2. Ectrophoresis analysis in $1 \%$ agarose gel of RT-PCR amplification products to detect CTV using primers reported by Rowhani et al. (1998). M: Marker 50 bp ladder; P: Positive control (CTV-infected).

Seven random oligonucleotide primers used and number of DNA fragments amplified in their presence are shown in (Table 7) and Fig. 3 out of seven (10mers) primers, four were succeeded and turned out to give number of banding in the gel depend on the genotype; three did not produce amplification products. Otherwise, most of the succeeded primers, identify DNA polymorphism, under our PCR condition showed that, the percentage of polymorphism depended on the primer tested and the genotype. This may be due to short size of the primers tested as suggested by Caetano-Anolles and Gresshoff (1992) for DNA fingerprinting.

As shown in (Table 7) and (Fig. 3) primers OPK01, and OPK02 succeeded with Washington navel orange, blood orange, lemon, grapefruit and sour orange and produced about 139 bands in the gel ranging from (100 to $1200 \mathrm{bp}$ ) in length , 22 out of these are polymorphic bands with 17.96\% ranging from (300 to 1000 bp) depending on the genotype and the primer tested. But primers OPK05 and 
OPK06 succeeded only with Shamouti orange and Local mandarin producing about 46 bands ranging from 250 to $1200 \mathrm{bp}$ in length, 8 bands out of them were polymorphic with $17.3 \%$ ranging from 300 to $1150 \mathrm{bp}$. The results demonstrate here that the RAPD-PCR technique can be successfully applied to determine the genetic stability of citrus plantlets that are produced through somatic embryogenesis.

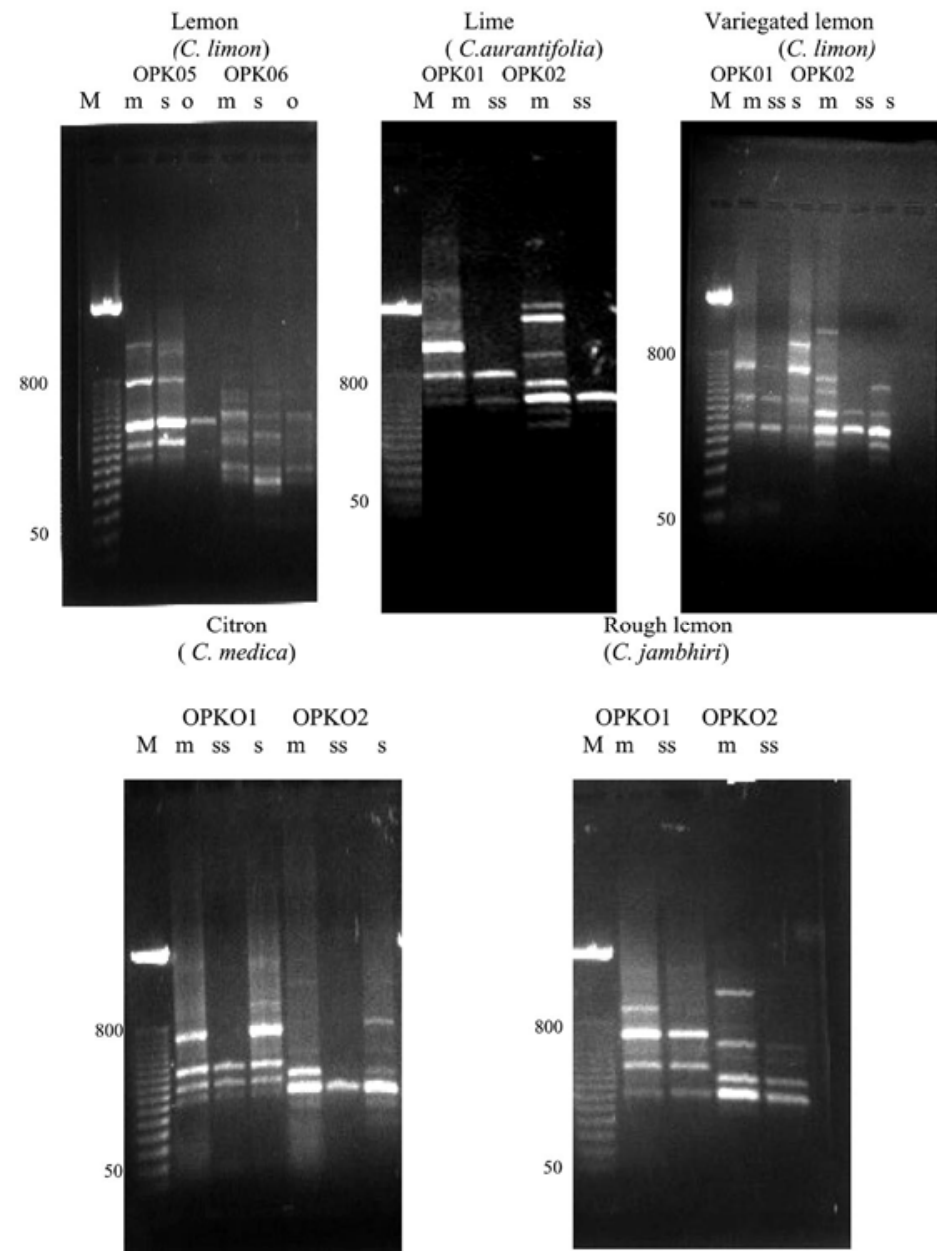

Fig. 3. Gel electrophoresis of RAPD fingerprints cbtained with primers $\mathrm{OPK}_{1}, \mathrm{OPK}_{2}, \mathrm{OPK}_{5}, \mathrm{OPK}_{6}$ of genomic DNA of 5 genotypes from style, stigma and ovary-derived plantlets of citrus. $\mathrm{M}$ : DNA marker 50 bp ladder; m: mother plant; s: style-derived plantlets; ss: stigma-derived plantlets; o: ovary-derived plantlets. 


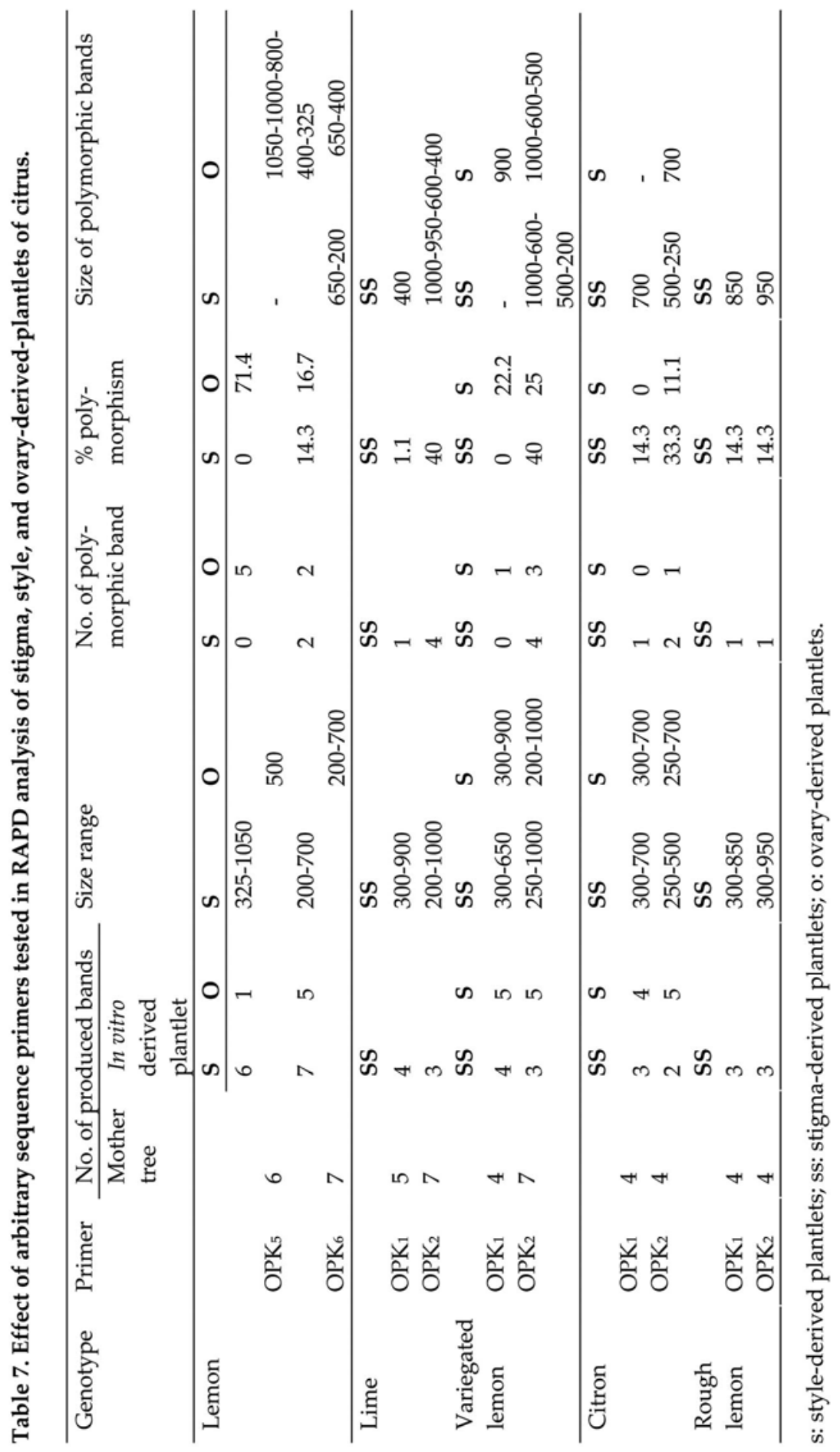




\section{References}

Angela Carra, Fabio De Pasqualez, Ada Ricci and Francesco Carimi (2006) Diphenylurea derivatives induce somatic embryogenesis in citrus. Plant Cell Tiss. Cult. 87: 41-48 .

Bitters WP, Murashige T, Rangan TS and Nauer E (1970) Investigations on established virus-free plants through tissue culture. Calif. Citrus Nursery Soc. 9: 27-30.

Button J and Bornman CH (1971) Development of nucellar plants from unpollinated and unfertilized ovules of the Washington navel orange in vitro. J. S. Afr. Bot. 37: 127-134

Benelli C, Germana MA, Ganino T and Beghe D (2010) .Morphological and anatomical observations of abnormal somatic embryos from anther cultures of Citrus reticulata. Biologia Plantarum 54(2): 224-230.

Caetano-Anolles G and Gresshoff PM (1992) Staining with silver. Promega Notes 45: 13-18.

Campion B, Azzimoni MT, Vicini E, Schiavi M and Falavigna A (1992) Advances in haploid plant induction in onion (Allium cepa L.) through in vitro gynogenesis . Plant Sci. 105: 81-86.

Carimi F, De pasquale F and Crescimanno FG (1995) Somatic embryogenesis in citrus from styles culture. Plant Sci. 105: 81-86.

Carimi F, De pasquale F and Crescimanno FG (1999) Somatic embryogenesis and plant regeneration from pistil thin cell layers of citrus. Plant Cell Reports 18: 935-940.

Carimi F, Tortorici MC, De Pasquale F and Crescimanno FG (1998) Somatic embryogenesis and plant regeneration from undeveloped ovules and stigma/style explants of sweet orange navel group (Citrus sisnetsis (L.) Osb.). Plant Cell, Tiss. Org. Cult. 54: 183-189.

Clark MF and Adams AN (1977) Characteristics of the microplate method for enzyme linked immunosorbent assay for the detection of plant viruses. J. Gen. Virol. 34: 475483.

Dabin P and Beguin F (1987) Somatic embryogenesis in Fuchsia. Acta Hortic. 212: 725726.

D'Onghia A M, Carimi F, De Pasquale F, Djelouah K and Martelli GP (2000) Somatic embryogenesis from style culture :A new technique for the sanitation, conservation and safe exchange of citrus germplasm. Proc. 9th Int. Soc. Citric.

D'Onghia A M, Carimi F, De pasquale F, Djelouah K and Martelli GP (2001) Elimination of citrus psorosis virus by somatic embryogenesis from stigma and style cultures. Plant Pathology 50: 266-269.

D'Onghia A M, De pasquale F, Carimi F, Savino V and Crescimanno FG (1997) Somatic embryogenesis from style culture as a possible means for virus elimination in citrus. J. Phytopath. 145: 77-79.

De Pasquale F, Carimi F and Crescimanno FG (1994) Somatic embryogenesis from styles of different cultivars of Citrus limon (L.) Burm. Aust. J. Bot. 42: 587-594.

Gaj MD (2004) Factors Influencing somatic embryogenesis induction and plant regeneration with particular reference to Arabidopsis thaliana(L.) Heynh. Plant Growth Regul 43: 27-47. 
Gholami AA, Alavi SV, Majd A and Fallahian F (2013) Plant regeneration through direct and indirect somatic embryogenesis from immature seeds of citrus. Europ. J. Expt. 3(3): 307-310.

Gill M, IS Singh Z, Dhillon BS and Gosal SS (1995) Somatic embryogenesis and plant regeneration in mandarin (Citrus reticulata Blanco). Scientia Horticulturae 63: 167-174.

Gill R, Gerrath JM and Saxena PK (1993) High-frequency direct somatic embryogenesis in thin layer cultures of hybrid seed geranium ( Pelargonium hortorum). Can. J. Bot. 71: 408-413.

Goussard PG, Wiid J and Kasdorf GGF (1991) The effectiveness of in vitro somatic embryogenesis in eliminating fanleaf virus and leafroll associated viruses from grape vines. S. Afr. J. Enol. Vitic. 12: 77-81.

Guedira M, Dubois Tylski T, Vasseur J and Dubois J (1988) Direct somatic embryogenesis from anthers and pistils of Cichorium. Plant Physiol. Biochem. 26: 212.

Hidaka T, Yamada Y and Shichijo T (1981) Plantlet formation from anthers of Citrus aurantium L. Proc. Int. Soc. Citriculture 1: 153-155.

Kiong ALP, Wan LS, Hussein S and Ibrahim R (2008) Induction of somatic embryos from different explants of citrus sinensis . J. Plant Sci. 3(1):18-32 .

Kobayashi S, Ikeda I and Nakatani M (1981) Role of primordium cell in nucellar embryogenesis in citrus. Proc. Int. Soc. Citriculture 1: 44-48.

Maheshwari P and Ranga Swamy NS (1958) Polyembryony and in vitro culture of embryos of Citrus and Mangifera. Indian J. Hort. 15: 275-282.

Mendes-da-Gloria FJ, Mourao Filho FAA and Appezzato da Gloria B (2001) Morfologia de embryones nucelares de laranja' Valencia' (Citrus sinensis (L.) Osbek). Acta bot. brasil. 15: 17-25.

Meziane M, Boudjeniba M, Frasheri D, Boukhalfa S and Braneci S (2012) Regeneration of Algerian citrus germplasm by stigma/style somatic embryogenesis. Afr. J. Biotec. 11(25): 6666-6672.

Murray MG and Thompson WF (1980) Rapid isolation of high molecular weight plant DNA. Nucleic Acids Res. 8: 4321-4325.

Nanda RM and Rout GR (2003). In vitro somatic embryogenesis and plant regeneration in Acacia arabica . Plant Cell Tiss. Org. Cult. 73:131-135.

Nito $\mathbf{N}$ and Iwamasa $\mathbf{M}$ (1990) In vitro plantlet formation from juice vesicle callus of Satsuma (Citrus unshiu Mare.). Plant Cell, Tiss. Org. Cult. 20(2): 137-140.

Niedz RP, Hyndman SE, Wynn ET and Bausher MG (2002) Normalizing sweet orange (C. sinensis (L.) Osbeck) somatic embryogenesis with semi-permeable membranes. In vitro Cell. Dev. Biol. Plant 38: 552-557.

Pasquali G and Biricolti S (2004) In vitro culture of ovules with nucelli and embryos of citrus. Adv. Hort.Sci.18(1)): 11-14

Ramirez C, Chiancon B, Testillano PS, Garcìa-Fojeda B, Germanà MA and Risuono MC (2003) First embryogenic stages of Citrus microspore-derived embryos. Acta Biol. Cracov. Bot. 45: 53-58.

Rangan TS, Murashige T and Bitters WP (1968) In vitro Initiation of nucellar embryos in monoembryonic citrus. HortSci. 3(4): 226-227. 
Rowhani A, Biardi L and Golino DA (1998) Detection of viruses of woody host plants using colorimetric PCR. Acta Hoticult. 472: 265-271.

Songstad DD and Conger BV (1986) Direct embryogenesis from cultured anthers and pistils of Dactylis glomerata. American J. Bot. 73: 989-992.

Starrantino A and Russo F (1980) Seedlings from undeveloped ovules of ripe fruits of polyembryonic citrus cultivars. HortScience 15(3): 296-297.

Straub PF, Decker DM and Gallagher JL (1992) Characterization of tissue culture initiation and plant regeneration in Sporobolus virginicus (Gramineae). Amer. J. Bot. 79: 1119-1125.

Tavano ECR, Stipp LCL, Muniz FR, Mourao Filho FAA and Mendes BMJ (2009) In vitro organogenesis of Citrus volkameriana and Citrus aurantium. Biol. Plant. 53: 395-399,

Tomaz ML, Mendes BMJ, Mourao Filho FAA, Demetrio CGB, Jansakul N and Rodriguez APM (2001). Somatic embryogenesis in Citrus spp: carbohydrate stimulation and histodifferentiation. In vitro Cell. Dev. Biol. Plant 37: 446-452.

Vardi A and Galun E (1989) Isolation and culture of Citrus protoplasts. In: Bajaj YPS (ed.), Biotechnology in Agriculture and Forestry. pp. 147-159. Springer-Verlag, BerlinHeidelberg.

Vardi A and Spiegel-Roy P (1992) Plant regeneration from Citrus protoplasts: variability in methodological requirements among cultivars and species. Theor. Appl. Genet. 72: 171-176.

Yang X and Quiros CF (1993) Identification and classification of celery cultivars with RAPD markers. Theor. Appl. Genet. 86: 205-212.

Zhou JY, Ma H, Guo FX and Luo XT (1994) Effect of thidiazuron on somatic embryogenesis of Cayratia japonica. Plant Cell Tiss. Org. Cult. 36: 73-79. 